\title{
På som panakeia
}

\author{
Preposisjonen på utvider sitt bruksområde. I medisinsk litteratur som i norsk språk for øvrig erstatter den \\ gradvis andre preposisjoner. Det gjør preposisjonsbruken enklere, men språket blir mindre variert.
}

«Ordet preposisjon betyr foranstilling, og preposisjonene står normalt foran det eller de ord de hører til», heter det på Riksmålsforbundets nettsider (1). Riktig preposisjonsbruk er krevende i alle språk, særlig i norsk. Vi bruker preposisjoner i nesten hver eneste setning vi skriver eller taler. Preposisjonene for, $i$, med, om, til og på er de vanligste (2).

\section{På - før og nå}

$P a ̊$ er en fusjonert preposisjon, opprinnelig sammensatt av opp og $a$. Den brukes svært mye i norsk, og har fătt hele 22 siders omtale i Norsk ordbok (3). Fire bruksområder av på beskrives: lokativ bruk (om steder), temporal bruk (om tid), om tilstander og formål og det som kalles «avbleikt tyding, knytt til andre innhaldsord» (3).

$P a ̊$ brukes først og fremst om det å sette noe i kontakt med noe annet, «på et bestemt sted». En hyppig diskutert problemstilling er om det skal brukes $p a ̊$ eller $i$ ved stedsnavn. Hovedregelen er at $i$ brukes om navn på land, kommuner og fylker og større byer (særlig ved kysten), mens på brukes på øyer og mindre byer og tettsteder (særlig $\mathrm{i}$ innlandet) (4).

Men det som først og fremst preger påbruken i våre dager, er ekspansjonen. $P a ̊$ er blitt en universalpreposisjon, en «preposisjonstyv» som stjeler seg inn på nye anvendelsesområder. Når man er i tvil om hvilken preposisjon som skal brukes, griper man lett til på. Dette er karakterisert som bruk av «på i utide» (5).

Ekspansjonen avspeiles i bruksfrekvensen i norske aviser, der økningen etter århundreskiftet er påfallende (fig 1). Flere nye bruksformer er registrert, bl.a. «vedrørende, når det gjelder» (f.eks. «samarbeide på sak») og «med grunnlag i» (f.eks. «selger godt på kvalitet») (6). Svedismen «å ta noe på alvor» er for lengst veletablert i norsk språk, mens det sannsynligvis er påvirkning fra engelsk («on») som forårsaker mye av på-syken.

\section{På i medisinske tekster}

I medisinsk litteratur tar nå på over for både $i$, om, til og over. Det heter ganske unisont å bli «innlagt på sykehus» (selv om Tidsskriftet så langt holder stand og skriver $i$ ).

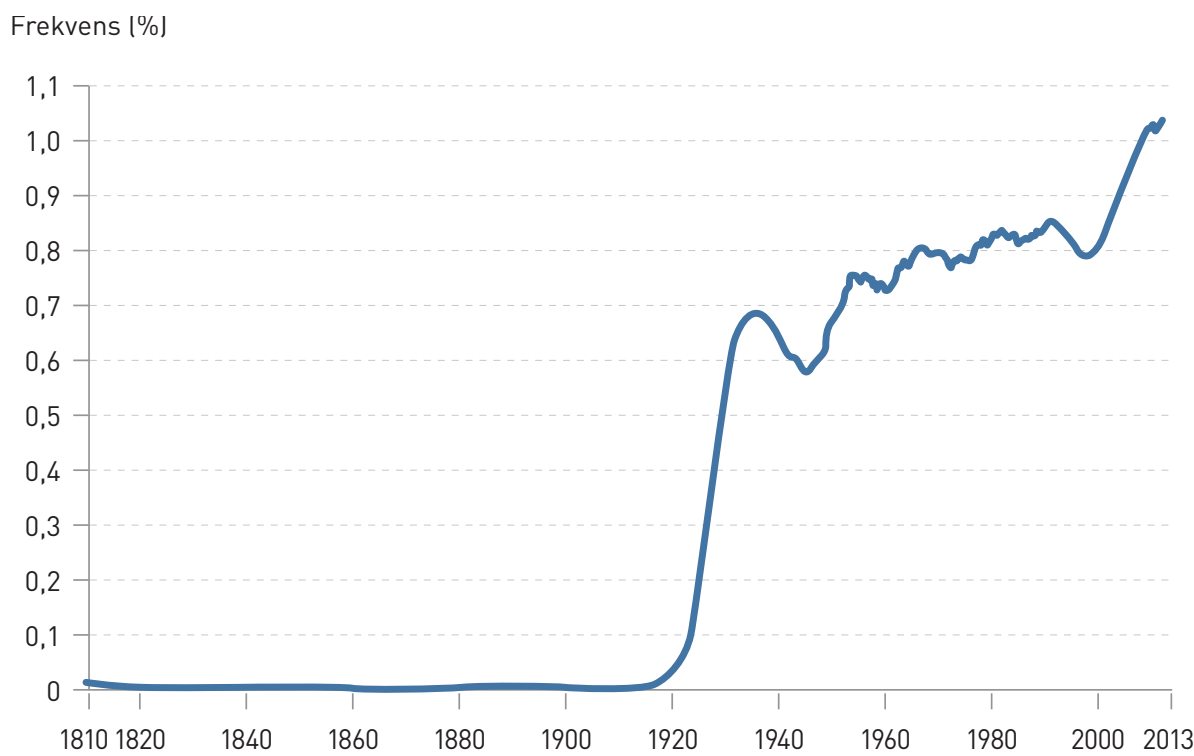

Figur 1 Frekvensen av ordet «på» i norske aviser, vist i Ngram, Nasjonalbibliotekets søketjeneste

Kolleger er «gode på rektoskopi» (ikke til å rektoskopere), de kan «konsentrere seg på denne oppgaven» (ikke om), og de har «kontroll på situasjonen» (ikke over). Man arbeider «på universitetet» (ikke ved) og «søker på PubMed» (ikke i). «På medisinstudiet» undervises det «på preklinikken», og i lunsjen har man endatil «diskusjon på» ulike temaer.

I gresk mytologi var Panakeia datter av Asklepios og gudinne for universell behandling og botemidler. Senere er panakeia, også bokstavert panasé eller panase, brukt som betegnelse på universalmedisin og midler som kan brukes til alle formål. Erfaring viser imidlertid at tiltak og midler som angivelig skal virke på alt, ofte ikke virker på noe. Omnipotens er sjelden et aktivum.

$P a ̊$ er blitt preposisjonenes universalmiddel. Det gjør kanskje preposisjonsbruken enklere, men det reduserer variasjonen og nyansene i språket. Og kanskje går det som med andre panakeia - at virkningen svekkes med utvidelsen av bruksområdet?
Magne Nylenna (f. 1952) er direktør for Kunnskapssenteret i Folkehelseinstituttet og professor II i samfunnsmedisin ved Universitetet i Oslo.

Litteratur

1. Preposisjoner. Riksmålsforbundet. www.riksmalsforbundet.no/grammatikk-eninnforing/ordklassene/preposisjoner/ (6.7.2016).

2. Aa LI. Mangfald og einskap med preposisjonar og vitskaplege krav til moderne ordbøker. I: Hagland JR, Wetås Å, red. Ivar Aasen ute og heime om moderne språkdokumentasjon etter Ivar Aasen. Det Kongelige Norske Videnskabers Selskabs Skrifter nr. 1/2015. Trondheim: Det Kongelige Norske Videnskabers Selskab, 2015: 110-25

3. På. I: Norsk ordbok. http://no2014.uio.no/perl/ ordbok/no2014.cgi?soek=p\%C3\%A5\#ariadne= [[|126281|,0,|på|

4. Gundersen D, red. På eller i ved stedsnavn. I: Språkvett. https://ordnett.no/språkverktøy/ språkvett.paaelleri (6.7.2016).

5. Gundersen D, red. På i utide. I: Språkvett. https://ordnett.no/språkverktøy/språkvett. paaiutide (6.7.2016).

6. Guttu T, Wangensteen B, red. Nyord i norsk. Oslo: Kunnskapsforlaget, 2012

Mottatt 8.7. 2016 og godkjent 18.7. 2016. Redaktør: Erlend Hem. 